\title{
PERSPEKTIF ANAK REMAJA TERHADAP PENJASKES
}

\author{
Eko Purnomo \\ Nina Jermaina \\ Eddy Marheni
}

\author{
Universitas Negeri Padang
}

Jln. Prof. Dr. Hamka, Air Tawar, Padang

Email/HP: ekopurnomo@fik.unp.ac.id/082376651233

\begin{abstract}
Abstrak
Pendidikan jasmani dan kesehatan (penjaskes) merupakan pelajaran yang lebih banyak mengasah kemampuan motorik dan gerak. Pembelajaran penjaskes yang dilakukan saat ini masih belum sesuai dengan yang diharapkan oleh pemerintah dan UU pendidikan. Masih banyak siswa yang salah atau kurang tepat dalam memaknai dan melaksanakan pembelajaran penjaskes tersebut, oleh karena itu merasa perlu untuk melakukan penelitian ini sebagai bahan evaluasi dan masukan sebagai pengajar calon guru di sekolah.

Tujuan dari penelitian ini adalah untuk melihat gejala-gejala yang mengakibatkan siswa SMA (anak remaja) enggan atau malas untuk melakukan pembelajaran penjaskes.

Metode yang digunakan adalah dengan melakukan wawancara dan pengamatan kepada siswa dan guru SMA yang tersebar di Kota Padang. Hasil yang didapat ada 2 temuan penelitian, pertama sebagian besar siswa enggan melakukan pembelajaran penjaskes dan sebagiannya lagi menyukai pembelajaran penjaskes dengan rincian dan keterangan terdapat pada hasil penelitian.

Kunci utama dari sebuah pengajaran di sekolah adalah menjadikan pelajaran tersebut menarik dan menyenangkan, sehingga membuat anak menjadi suka terhadap pelajaran tersebut, khususnya penjaskes. Setelah itu, maka siswa akan melakukan pembelajaran tersebut dengan sendirinya tanpa adanya instruksi atau bahkan paksaan dari guru (self discipline)
\end{abstract}

Keyword: Anak Remaja, Penjaskes, Psikologi Olahraga

\section{PENDAHULUAN}

Berdasarkan Undang-undang Sistem

Pendidikan Nasional No. 20 tahun 2003

disebutkan bahwa tujuan pendidikan

adalah untuk mengembangkan potensi anak didik agar menjadi manusia yang beriman dan bertakwa kepada Tuhan Yang Maha Esa, berahlak mulia, sehat, berilmu, cakap, kreatif, mandiri, dan menjadi warga Negara yang demokratis 
serta bertanggung jawab. Sedangkan tujuan pendidikan jasmani (penjaskes) berdasarkan SK Menpora nomor 053A/MENPORA/1994 "Pendidikan jasmani adalah suatu proses pendidikan yang dilakukan secara sadar dan sistematis melalui berbagai kegiatan jasmani dalam rangka memperoleh kemampuan dan keterampilan jasmani, pertumbuhan fisik, kecerdasan dan pembentukan watak". Akan tetapi permasalahan yang dihadapi adalah sering tidak tercapai dari tujuan penjaskes tersebut. Berikut sepuluh alasan mengapa remaja membutuhkan pendidikan jasmani yang berkualitas (Masurier, 2006):

\begin{abstract}
Reason 1: Regular Physical Activity Helps Prevent Disease, Reason 2: Regular Physical Activity Promotes Lifetime Wellness, Reason 3: Quality Physical Education Can Help Fight Obesity, Reason 4: Quality Physical Education Can Help Promote Lifelong Physical Fitness, Reason 5: Quality Physical Education Provides Unique Opportunities for Activity, Reason 6: Quality Physical Education Teaches Self-Management and Motor Skills, Reason 7: Physical Activity and Physical Education Promote Learning, Reason 8: Regular Physical Activity Participation Makes Economic Sense, Reason 9: Physical Education Is Widely Endorsed, Reason 10: Quality Physical Education Helps to Educate the Total Child
\end{abstract}

Tidak tercapainya tujuan penjaskes itu sendiri seperti yang dijelaskan Habibie (Ruindungan, 1996: 8) dalam hasil pengamatannya bahwa sistem pendidikan kita belum memberi ruang yang lebih luas bagi pengembangan kemampuan kreatif, khususnya kreativitas berpikir anak. Permasalahan lain karena tingginya konsumsi teknologi mengakibatkan malasnya siswa untuk bergerak dan beraktivitas fisik lainnya. School physical education programs are the ideal setting for teaching youth the benefits of leading a healthy lifestyle (Houston. 2014)

Partisipasi aktivitas fisik secara teratur sepanjang masa kanak-kanak memberikan manfaat kesehatan langsung, dengan secara positif mempengaruhi komposisi tubuh dan perkembangan muskulo-skeletal (Malina dan Bouchard, 1991), dan mengurangi keberadaan faktor risiko penyakit jantung koroner (Gutin et al., 1994). In recognition of these health benefits, physical activity guidelines for children and youth have been developed by the Health Education Authority [now Health Development Agency (HDA)] (Biddle et al., 1998). Rekomendasi lain yang diberikan untuk menunjang pembelajaran di sekolah adalah dengan melakukan aktivitas fisik 1 jam per hari dengan intensitas setidaknya sedang (seperti jalan cepat), melalui gaya 
hidup, adalah bentuk aktivitas rekreasi dan terstruktur.

A secondary recommendation is that children take part in activities that help develop and maintain musculo-skeletal health, on at least two occasions per week (Biddle et al., 1998). Target ini dapat diatasi melalui kegiatan menahan beban yang fokus pada pengembangan kekuatan otot, daya tahan dan fleksibilitas, dan kesehatan tulang.

Pendidikan jasmani dan kesehatan (penjaskes) di sekolah memberikan konteks untuk mengikuti aktivitas fisik yang teratur dan terstruktur. Untuk tujuan tersebut, maka penjaskes diatur dalam kurikulum sekolah yang tujuannya ialah sebagai kontribusi terhadap kesehatan dan kebugaran anak-anak

The important role that PE has in promoting health-enhancing physical activity is exemplified in the US 'Health of the Nation' targets. These include three PE-associated objectives, two of which relate to increasing the number of schools providing and students participating in daily PE classes. The third objective is to improve the number of students who are engaged in beneficial physical activity for at least $50 \%$ of lesson time (US Department of Health and Human Services, 2000).

Pada tahun 2000 US melalui departemen kesehatannya, ada 3 aspek penting dalam kegiatan penjaskes di sekolah, pertama mempromosikan aktivitas fisik. Kedua, penjaskes sebagai bentuk adaptasi kegiatan fisik kepada siswa, dan ketiga menambah lebih banyak siswa yang gemar berolahraga. Artinya memang benar bahwasanya penjaskes dijadikan alat untuk membuat suatu kebiasaan atau adaptasi untuk selalu melakukan aktivitas fisik.

Penjelasan di atas menunjukkan begitu pentingnya penjaskes untuk kelangsungan hidup siswa tersebut. Disisi lain penjaskes di Indonesia masih belum dianggap penting oleh sebagian besar siswa maupun orang tua, hingga akhirnya, aktivitas fisik sering ditinggalkan. Pemahaman dan pandangan khususnya oleh siswa yang sering salah terhadap penjaskes membuat penjaskes malas dan banyak ditinggalkan. Nantinya hasil penelitian ini dapat dijadikan oleh guru dalam melakukan pengajaran penjaskes disekolah, khususnya bagi anak remaja (SMA).

\section{METODE}

Jenis penelitian yang digunakan pada penelitian ini yaitu penelitian kualitatif, yang dilaksanakan dari bulan FebruariApril 2018. Selain itu proses wawancara 
dan dokumentasi juga dilakukan saat pengambilan data. Sampel untuk penelitian ini dipilih karena beberapa alasan tertentu. In order to gather information that creates a greater understanding of how student experience having a sport psychology consultant, data was collected from individuals who directly experienced the phenomena of interest (Patton, 2002). Subjek yang digunakan diambil secara kebutuhan, antara lain SMA N 7, SMA 6 dan SMA $\mathrm{N}$ 10. Teknik dan alat pengumpulan datanya menggunakan metode observasi, wawancara dan dokumentasi. Teknik analisis data dalam Penelitian ini adalah lebih banyak bersifat uraian dari hasil observasi, wawancara dan dokumentasi. Data yang telah diperoleh akan dianalisis secara kualitatif serta diuraikan dalam bentuk deskriptif (Patton, 2001:103). Analisis data adalah "proses mengatur urutan data, mengorganisasikannya ke dalam suatu pola, kategori dan uraian dasar". Teknik analisis data yang digunakan dalam penelitian ini adalah menggunakan langkah-langkah seperti yang dikemukakan oleh Burhan Bungin (2003:70), yaitu sebagai berikut:

a. Pengumpulan data (data collection) b. Reduksi data (data reduction)

c. Display data

d. Verifikasi dan penegasan kesimpulan (conclution drawing and verification)

\section{HASIL}

\section{TEMUAN PERTAMA}

\section{Penjaskes sebagai pelarian di kelas}

Sebagian besar siswa SMA mengatakan bahwa, pelajaran penjaskes adalah tempat atau waktu pelarian karena jadwal yang sangat padat di dalam kelas. Dengan belajar yang terus menerus di dalam kelas dari pagi sampai dengan siang hari, siswa mengalami kebosanan dan kejenuhan dalam berfikir, dan mereka akan lebih leluasa dalam berbincang-bincang di lapangan dibandingkan di dalam kelas, karena jika di dalam kelas "ribut/berisik" maka para guru akan mendengar dan mengetahuinya

\section{Penjaskes bukan sebagai pelajaran yang penting}

Pemikiran yang sampai saat ini masih ada pada siswa adalah, penjaskes bukan yang penting, seperti IPA, Metematika, Bahasa maupun IPS. Selain itu, mereka mengatakan penjaskes tidak dapat 
membuatnya tinggal kelas. Karena merasa tidak penting pelajaran penjaskes tersebut membuat siswa malas dalam pembelajaran.

\section{Penjaskes hanya tempat bermain}

Ketika waktu pelajaran penjaskes, mereka lebih banyak bermain, bercanda dan kurang serius dalam pembelajaran berlangsung. Fokus dan tujuan yang disampaikan oleh guru kepada siswa mengenai penjaskes masih belum dapat diterima dan diterapkan oleh siswa, dan hal tersebut menjadikan siswa selalu bermain-main dalam setiap pembelajaran penjaskes.

\section{Kesadaran akan gerak yang ku- rang}

Sebagian besar dari siswa masih belum sadar akan pentingnya penjaskes khususnya dalam pembelajaran gerak itu sendiri, mereka masih beranggapan bahwa untuk menjadi polisi, guru, dokter atau profesi lainnya tidak memerlukan mata pelajaran penjaskes.

\section{Faktor guru}

Pengajaran yang membosankan juga menjadi faktor siswa tidak menyukai dan kurang menganggap penting penjaskes tersebut, guru yang terlalu sibuk dengan kegiatan luar (seperti O2SN, Porseni, Porprov dan lainnya) membuat mereka hanya mendapatkan tugas mandiri seperti menulis dan mengerjakan LKS). Selain itu, guru juga disibukkan dengan pembuatan perangkat pembelajaran, dan sebagian besar guru juga belum sepenuhnya menerapkan perangkat pembelajaran yang dibuat.

Faktor lain yang dialami guru adalah masih banyak guru yang belum mengerti tentang pengoperasian komputer/laptop dan ditambah lagi tentang pengetahuan yang kudet (kurang update). Hal tersebut banyak terjadi kepada guru yang berumur di atas 4 tahun masa dinas.

Selain itu tingkat kreatifitas guru juga menjadi faktor penting dalam membuat pengajaran penjaskes membuat lebih menarik dan disukai oleh para siswa.

\section{Dukungan orang tua}

Ketika berhadapan langsung dengan siswa, mereka menjelaskan orang tua mereka juga tidak menganggap penting pelajaran penjaskes. Hal tersebut didukung oleh siswa yang disibukkan dengan kelas tambahan yang dapat membuat meraka lulus dalam pencarian 
perguruan tinggi seperti PTN, PTS dan ikatan dinas.

\section{Pemanfaatan sarana dan prasara- na}

Jika berbicara mengenai sarana dan prasarana, maka bisa dikatakan sebagian besar sekolah yang berada di Indonesia memiliki sarana dan prasarana yang tidak mencukupi, akan tetapi pemanfaatannya diusahakan semaksimal mungkin, membuat pembelajaran hanya menggunakan sarana prasarana itu-itu saja dan sesuai dengan tuntutan kurikulum.

\section{Motivasi belajar}

Khususnya pada beberapa sekolah di Kota Padang, penjaskes dilakukan setelah jam pelajaran sekolah, artinya jika sekolah dilakukan pada pukul 07.00-13.30 WIB maka, pembelajaran dilakukan pada pukul 14.00 WIB sebagian besar siswa merasa hal tersebut menjadi beban waktu, selain itu jadwal tersebut juga mengganggu jadwal kelas tambahan bagi siswa, khususnya pada kelas XII yang akan menghadapi ujian nasional, pelajaran penjaskes juga sering terganggu seperti dengan kegiatan ujicoba ujian nasional (try out). Bagi siswa kelas $\mathrm{X}$ dan $\mathrm{XI}$ jadwal tersebut harusnya mereka jadikan waktu untuk bermain dan beristirahat, karena sudah seharian belajar di sekolah.

\section{TEMUAN KEDUA}

Akan tetapi tidak semua siswa tidak menyukai penjaskes, ada beberapa siswa dalam setiap kelas menyukai pembelajaran penjaskes, hal tersebut dikarenakan:

1. Siswa memiliki bakat dan minat dibidang olahraga (tetapi tidak semua cabang olahraga).

2. Siswa menyadari kemampuannya di pelajaran lain (seperti IPA, Matematika, IPS dan Bahasa) tidak ada.

3. Adanya dukungan orang tua.

4. Mengetahui bahwa prestasi seperti olahraga dan seni juga dapat dijadikan modal masuk dalam perguruan tinggi yang diinginkan melalui jalur prestasi.

5. Pembelajaran penjaskes dapat merefresh daya ingat atau pemikiran yang terlampau penat.

\section{PEMBAHASAN}

Proses pembelajaran penjaskes di SMA yang ada di Kota Padang mengalami beberapa permasalahan. Seperti kurangnya dukungan orang tua, motivasi 
yang rendah, serta masih dikesampingkan fungsi dan tujuan dari penjaskes tersebut. Selain itu cara mengajar guru yang masih bersifat tradisional dan guru yang "gaptek" membuat pembelajaran yang harusnya berkembang menjadi jalan ditempat atau stagnant. Disisi lain seharusnya guru dapat lebih aktif dan kreatif dalam membuat pembelajaran di sekolah justru hanya mengandalkan ilmu yang pernah diperoleh saat di bangku perkulihan, dan ilmu yang diterapkan pun juga masih ilmu yang tidak update (terbaru).

Temuan lain dari penelitian ini adalah, terdapat siswa yang sangat antusias dalam setiap pembelajaran penjaskes, hal tersebut dapat dilihat ketika dalam pembelajaran berlangsung, siswa selalu bersemangat, rajin, dan mengikuti setiap instruksi yang diberikan oleh guru. Fakta lain yang didapatkan, ternyata siswa yang antusias dalam pembelajaran penjas tidak terlalu menyukai pembelajaran di kelas, siswa mengungkapkan jika belajar di kelas akan membuat mengantuk dan membosankan. Selain itu, minat terhadap mata pelajaran di kelas seperti berhitung dan mengolah rumus bukan merupakan bakat ataupun minat dari diri siswa tersebut. Se- dangkan kegiatan luar kelas, seperti olahraga dan seni merupakan minat dari siswa tersebut.

Effective physical education can provide children with the tools for participating in safe and healthy activities throughout their lives (Houston. 2014).

Lebih lanjut penelitian ini melalui wawancara, siswa yang aktif dan selalu bersemangat dalam pembelajaran penjaskes adalah siswa yang kesehariannya melakukan aktivitas fisik, seperti berlari, sepak bola, futsal, basket atau bahkan hanya sekedar melakukan aktivitas permainan tradisional sederhana. Sedangkan, siswa yang memang tidak atau kurang menyukai pembelajaran penjaskes adalah siswa yang malas untuk bergerak, malas berkeringat, selalu tampil menarik (lebih banyak perempuan) dan bahkan membaca buku, serta lebih suka bermain sosial media dan bermain games online.

\section{SIMPULAN}

Penjelasan di atas dapat kita simpulkan bahwa, siswa mempunyai bakat dan minatnya masing-masing. Ada yang gemar beraktivitas gerak ada pula yang enggan atau tidak menyukainya. Tetapi sebagai seorang guru, seharusnya mem- 
berikan pembelajaran tersebut kepada siswa sebagai bekal untuk dirinya sendiri, walau bukan untuk pekerjaan dan atau hobby. Akan tetapi sebagai cara untuk menyegarkan atau menyehatkan diri sendiri sesuai dengan ajaran agama dan UU tentang Sistem Keolahragaan Nasional tahun 2005.

Pembelajaran penjaskes yang menyenangkan dapat membuat melakukan kegiatan gerak secara otomatisasi (dengan sendirinya) akan tetapi pembelajaran yang membosankan dan tidak menarik justru akan membuat tidak ingin lagi atau berhenti untuk melakukan aktivitas gerak.

Melakukan kegiatan fisik dan berolahraga disekolah melalui pembelajaran penjaskes serta belajar mengenai nilai-nilai falsafah olahraga, dapatmenjadikan salah satu cara untuk mengintervensi perkembangan karakter anak bangsa melalui disiplin atau pun nilai-nilai sportifitas yang ada didalam pembelajaran penjaskes.

\section{DAFTAR RUJUKAN}

Ayi Suherman, (2010) Model Pembelajaran Pakem Dalam Pendidikan Jasmani Di Sekolah Dasar, Jurnal Penelitian Pendidikan Vol. 11 No. 1 April 2010
Biddle, S., Sallis, J.F. and Cavill, N. (eds) (1998) Young and Active? Young People and HealthEnhancing Physical Activity Evidence and Implications. Health Education Authority, London.

Gutin, B., Islam, S., Manos, T., Cucuzzo, N., Smith, C. and Stachura, M.E. (1994) Relation of body fat and maximal aerobic capacity to risk factors for atherosclerosis and diabetes in black and white sevento-eleven year old children. Journal of Pediatrics, 125, 847-852.

Houston, Jennifer \& Kulinna, Pamela (2014) Health-Related Fitness Models in Physical Education, Strategies: A Journal for Physical and Sport Educators. Volume 27 March/April 2018

Malina, R.M. and Bouchard, C. (1991) Growth, Maturation and Physical Activity. Human Kinetics, Champaign, IL.

Masurier,Guy Le., Corbin, Charles B. (2006) Top 10 Reasons for Quality Physical Education, JOPERD Volume 77 No. 6 August 2006

Patton, M.Q. (2002). Qualitative Research and Evaluation Methods ( $3^{\text {rd }}$ ed.). Thousand Oaks, CA: Sage Publications, Inc.

SK Menpora nomor 053A/MENPORA/1994

Undang-undang Republik Indonesia Nomor 20 Tahun 2003 Tentang Sistem Pendidikan Nasional

US Department of Health and Human Services (2000) Healthy People 2010: Understanding and Improving Health. USDHHS, Washington DC. 